\title{
HUBUNGAN ANTARA BEBAN KERJA FISIK DAN BEBAN KERJA MENTAL BERBASIS ERGONOMI TERHADAP TINGKAT KEJENUHAN KERJA PADA KARYAWAN PT JASA MARGA (PERSERO) TbK CABANG SURABAYA GEMPOL
}

\author{
Moch. Zulfiqar Afifuddin Rizqiansyah \\ Fakultas Pendidikan Psikologi Universitas Negeri Malang \\ rizqiansyah21@gmail.com
}

Fattah Hanurawan

Prodi Psikologi, Fakultas Pendidikan Psikologi, Universitas Negeri Malang

\section{Ninik Setiyowati}

Prodi Psikologi, Fakultas Pendidikan Psikologi, Universitas Negeri Malang

\begin{abstract}
Abstrak
Kejenuhan kerja (burnout) dapat diketahui dari adanya kelelahan fisik, mental, dan emosional, serta rendahnya penghargaan terhadap diri sendiri. Salah satu indikator penyebab timbulnya kejenuhan kerja (burnout) adalah beban kerja fisik maupun beban kerja mental. Beban kerja fisik maupun beban kerja mental sangat erat kaitannya dengan kajian ergonomi. Dari sudut pandang ergonomi, beban kerja fisik masuk dalam dimensi ergonomi fisik sedangkan beban kerja mental masuk dalam dimensi ergonomi kognitif. Metode penelitian yang digunakan adalah deskriptif dan korelasional dengan tujuan untuk mengetahui adanya hubungan antara variabel bebas yaitu Beban Kerja Fisik berbasis ergonomi $\left(\mathrm{X}_{1}\right)$ dan Beban Kerja Mental berbasis ergonomi $\left(\mathrm{X}_{2}\right)$ dengan variabel terikat yaitu Kejenuhan Kerja (Burnout) (Y). Populasi penelitian adalah 70 karyawan staf non operasional PT Jasa Marga (Persero) Tbk cabang Surabaya Gempol. Teknik sampling yang digunakan adalah purposive sampling dengan jumlah sampel karyawan staf non operasional PT Jasa Marga (Persero) Tbk cabang Surabaya Gempol sebanyak 30 orang. Hasil penelitian menunjukkan bahwa seluruh koefisien korelasi tidak signifikan sehingga hipotesis penelitian ditolak, dengan uraian sebagai berikut: (1) signifikansi antara $X_{1}$ dan $Y$ sebesar 0,896; (2) signifikansi antara $\mathrm{X}_{2}$ dan $\mathrm{Y}$ sebesar -0,130; dan (3) signifikansi regresi antara $\mathrm{X}_{1}, \mathrm{X}_{2}$, dan $\mathrm{Y}$ sebesar 0,728 . Kesimpulan hasil penelitian yaitu beban kerja fisik dan beban kerja tidak DAPAT memprediksi terjadinya kejenuhan kerja (burnout) pada karyawan sehingga dimungkinkan banyak faktor lain yang dapat mempengaruhi terjadinya kejenuhan kerja (burnout).
\end{abstract}

Kata kunci : beban kerja fisik, beban kerja mental, ergonomi, kejenuhan kerja (burnout)

Seiring perkembangan zaman, kebutuhan akan pekerjaan dalam bidang industri dan organisasi di Indonesia pun akan berkembang. Dengan sumber daya manusia yang terus bertambah, maka tuntutan mendapatkan lapangan pekerjaan pun akan bertambah. Persaingan mendapat pekerjaan di bidang industri tentu akan semakin ketat. Apabila tidak ada perencanaan dan pengelolaan yang tepat oleh para ahli bidang Human Resources Development (HRD) maka akan banyak sumber daya manusia terbuang sia-sia. HR Manager dari perusahaan harus memiliki perencanaan sumber daya manusia yang baik untuk memperkirakan jumlah ideal karyawan yang dibutuhkan dalam suatu pekerjaan. Hal-hal yang dibutuhkan untuk menentukan jumlah karyawan pada setiap unit pekerjaan adalah informasi mengenai beban kerja setiap karyawan pada setiap unit di perusahaan. Workload tidak hanya menghitung waktu yang dihabiskan untuk pekerjaan produktif tetapi juga termasuk menghitung aspek individu manusia, seperti kelelahan, kebutuhan pribadi, dan faktor kelonggaran (Barnes dalam Hutagalung \& Gustomo, 2013).

Perhitungan beban kerja dalam sebuah perusahaan sangat penting. Beban kerja (workload) mengacu pada intensitas penugasan kerja. Ini merupakan sumber stres karyawan (Shah et al., 2011). Secara spesifik, beban kerja dapat dibagi dua, yaitu beban kerja fisik dan 
mental. Beban fisik cenderung mengarah pada beban yang diterima seorang karyawan dalam suatu pekerjaan yang berkaitan dengan kondisi fisiologisnya, seperti kebisingan, vibrasi (getaran), dan hygiene. Apabila kondisi kerja yang demikian cukup buruk, maka akan terjadi stres kerja dengan gejala fisikal, seperti tekanan darah tinggi, diare, obstipasi, dll (Cooper dalam Munandar, 2001). Job description yang berlebih karena terbatasnya jumlah karyawan merupakan indikasi adanya beban kerja fisik yang berlebih. Sedangkan persepsi terhadap ketidaksesuaian kerja dan lingkungan kerja yang menimbulkan stres merupakan indikasi adanya beban kerja mental yang berlebih.

Berdasarkan uraian di atas, maka sangat penting adanya analisis beban kerja sebagai dasar optimalisasi sumber daya manusia. Analisis beban kerja banyak digunakan dalam berbagai lingkup kebutuhan, salah satunya adalah analisis ergonomi. Menurut Kristanto \& Manopo (2010) ergonomi berkenaan dengan optimasi, efisiensi, kesehatan, keselamatan, dan kenyamanan manusia di tempat kerja, di rumah, dan tempat rekreasi. Singkatnya, ergonomi adalah ilmu yang mempelajari manusia dalam hubungannya dengan pekerjaan, dengan segala aspek dan ruang lingkupnya. Pekerjaan yang tidak ergonomis akan menyebabkan ketidaknyamanan, biaya tinggi, penurunan performa, efisiensi, daya kerja dan kecelakaan. Dari sudut pandang ergonomi, antara tuntutan tugas dengan kapasitas kerja harus selalu seimbang sehingga dicapai performansi kerja yang tinggi. Dalam kata lain, tuntutan tugas tidak boleh terlalu rendah (underload) dan juga tidak boleh terlalu berlebihan (overload) karena keduanya menyebabkan stres.

Kelelahan dan stres yang disebabkan kondisi fisik, emosi dan mental yang buruk akibat situasi kerja yang berat dalam jangka panjang akan berakibat kejenuhan kerja (burnout). Burnout menggambarkan kondisi emosional seseorang yang merasa lelah dan jenuh secara mental, emosional, dan fisik akibat tuntutan kerja yang meningkat. Menurut Cicilia Maslach (dalam Rahman, 2007) burnout memiliki pengertian multidimensional, berupa sindrom psikologis yang terdiri dari tiga dimensi, yaitu : (1) kelelahan emosional, (2) depersonalisasi, dan (3) low personal accomplishment. Dale (dalam Maharani \& Triyoga, 2012) menyatakan bahwa kejenuhan kerja menjadi masalah bagi organisasi bila mengakibatkan penurunan kinerja dan produktivitas. Lingkungan kerja yang buruk juga menurunkan motivasi karyawan.

Dari penjabaran di atas, maka beban kerja fisik maupun mental yang berlebih dapat berdampak negatif terhadap organisasi atau perusahaan karena terjadi kejenuhan kerja (burnout) pada karyawan. Dengan memperhitungkan aspek waktu, teknis, dan sistem dalam melakukan pekerjaan, dapat diketahui beban kerja yang diterima oleh seorang pegawai. Bila ditemukan beban kerja berlebih pada seorang karyawan, maka dapat dilakukan reformasi jabatan. Reformasi jabatan dapat dilakukan ketika memang dirasa perlu untuk merekrut dan menambah sumber daya manusia untuk mengisi kekosongan jabatan sehingga akan mengurangi beban kerja pada seorang karyawan.

\section{METODE}

Penelitian ini merupakan penelitian deskriptif korelasional. Terdapat tiga variabel yang akan diuji dalam penelitian ini, yaitu : (1) Beban kerja fisik berbasis ergonomi (X1), (2) Beban kerja mental berbasis ergonomi (X2), dan (3) Kejenuhan kerja (Burnout) (Y). Populasi penelitian ini adalah 70 karyawan staf non operasional PT Jasa Marga (Persero) Tbk Cabang Suarabaya Gempol dengan jumlah sampel 30 orang yang diperoleh dengan teknik purposive sampling.

Dalam penelitian ini, terdapat tiga alat ukur, yaitu alat ukur beban kerja fisik (physiological workload), beban kerja mental (psychological workload), dan kejenuhan kerja (burnout). Untuk mendapatkan hasil penghitungan beban kerja fisik, dilakukan perhitungan dengan metode penghitungan tidak langsung, yaitu menghitung denyut nadi karyawan dalam bekerja untuk mendapatkan hasil \%CVL (Cardiovasculair Load) dari Kilbon (1992). Penghitungan beban kerja mental, dilakukan pengukuran dengan menggunakan Skala NASA-TLX (Task Load Index) dari Hart \& Staveland (1988) yang 
memuat enam indikator untuk diukur. Sedangkan kejenuhan kerja (burnout) akan diukur dengan menggunakan kuesioner yang diadaptasi dari Maslach Burnout Inventory (MBI) dari Maslach, dkk, yang memuat tiga dimensi utama dari penyebab terjadinya burnout, yaitu exhaustion, depersonalization, dan personal achievement. Ketiga alat ukur tersebut telah baku secara teori dan teruji tingkat validitas dan reliabilitasnya. Selain itu, ketiga alat ukur ditambahkan uji validitas ahli dari kedokteran dan ahli bahasa Inggris.

\section{Penghitungan Beban Kerja Fisik (\% CVL)}

Penghitungan dilakukan dengan menghitung denyut nadi karyawan dengan metode 10 denyut. Rumus penghitungannya adalah sebagai berikut.

$$
\text { Denyut Nadi }=\frac{10 \text { Denyut }}{\text { Waktu Penghitungan }} \times 60
$$

Pengukuran 10 denyut, dilakukan dua kali untuk mendapatkan nilai DNI (Denyut Nadi Istirahat) dan DNK (Denyut Nadi Kerja). Pengambilan DNI dilakukan pada saat sebelum karyawan memulai pekerjaannya. Sedangkan pengambilan DNK dilakukan pada saat karyawan mulai bekerja. Setelah mendapatkan nilai DNI dan DNK, maka selanjutnya dilakukan perhitungan Cardiovasculair Strain (\%CVL). Rumus perhitungan \%CVL adalah sebagai berikut.

$$
\% C V L=\frac{100 \times(D N K-D N I)}{D N \max -D N I}
$$

DNmax ditentukan dengan cara sebagai berikut : (1) Pria $=220$ - usia; (2) Wanita $=200$ - usia. Dari hasil perhitungan \%CVL, maka akan didapatkan nilai atau indeks beban kerja fisik yang diterima oleh karyawan. Klasifikasi beban kerja fisik berdasarkan \%CVL adalah sebagai berikut :

Tabel 1. Klasifikasi Beban Kerja Fisik

\begin{tabular}{cl}
\hline Range $(\%)$ & \multicolumn{1}{c}{ Klasifikasi } \\
\hline$<30$ & Tidak terjadi kelelahan \\
\hline 30 s.d. $<60$ & Diperlukan perbaikan \\
\hline 60 s.d. $<80$ & Kerja dalam waktu singkat \\
\hline 80 s.d. $<100$ & Diperlukan tindakan segera \\
\hline
\end{tabular}

$>100 \quad$ Tidak diperbolehkan beraktivitas Sumber : Simanjuntak, (2011)

\section{Penghitungan Beban Kerja Mental (NASA-} TLX)

Berdasarkan Buku Manual NASA Task Load Index (TLX) Paper and Pencil Package yang diterbitkan oleh Human Performance Research Group NASA Ames Research Center Moffett Field, California, terdapat tiga bagian dalam perhitungan beban kerja mental menggunakan NASA Task Load Index (TLX), yaitu : (1) Sources of Load (Weights), yaitu pemberian bobot; (2) Magnitude of Load (Ratings), yaitu pemberian rating; dan (3) Weighting and Averaging Procedure, yaitu penghitungan rata-rata dari hasil pembobotan rating.

Dalam skala NASA TLX, terdapat lima indikator yang akan diukur yaitu: (1) Physical Demand, (2) Temporal Demand, (3) Performance, (4) Effort, dan (5) Frustration Level. Tahap pertama adalah melakukan pembobotan untuk mendapatkan nilai Sources of Load. Hal ini dilakukan dengan cara memberikan kuesioner kepada subjek penelitian yang berisi 15 pasang indikator. Subjek diharuskan untuk memilih salah satu (dengan cara melingkari) dari indikator dari setiap pasang, yang dirasa memberi beban lebih dalam bekerja. Hasil dari indikator yang dipilih, di tally untuk mendapatkan bobot dari setiap indikator.

Setelah itu, dilakukan penghitungan Magnitude of Load, yaitu memberikan rating terhadap lima indikator. Subjek diminta memberikan respon dengan memberi tanda pada rentang skala yang telah ditentukan. Setelah mendapatkan rating, dilakukan Weighting and Averaging Procedure, yaitu menghitung ratarata Weighted workload (WWL) dengan cara mengalikan Weight dengan Rating. Jumlah keseluruhan dari pengalian itu dibagi 15 . Selanjutnya, dilakukan kategorisasi beban kerja mental berdasarkan klasifikasi berikut :

Tabel 2. Klasifikasi Beban Kerja Mental

\begin{tabular}{cc}
\hline $\begin{array}{c}\text { Kategori Beban Kerja } \\
\text { Mental }\end{array}$ & $\begin{array}{c}\text { Nilai Rata-Rata } \\
\text { WWL }\end{array}$ \\
\hline Agak ringan & $<50$ \\
Sedang & $50-80$ \\
\hline
\end{tabular}




$\begin{array}{cc}\text { Berat } & >80 \\ \text { Sumber : Hart \& Staveland (dalam Ramadhania \& } \\ \text { Parwati, 2015) }\end{array}$
Parwati, 2015)

\section{Pengukuran Burnout menggunakan Maslach Burnout Inventory (MBI) \\ Maslach Burnout Inventory (MBI)} telah diakui sejak lama sebagai salah satu alat ukur yang dapat digunakan untuk mengukur burnout. MBI memuat tiga skala, yaitu : (1) Emotional Exhaustion, untuk menghitung perasaan dan emosi yang terlibat secara berlebihan dan kelelahan pada suatu pekerjaan, (2) Depersonalization, menghitung respon perasaan dalam bertemu dengan klien atau orang lain yang berhubungan dengan pekerjaan, dan (3) Reduced of Personal Accomplishment, menghitung perasaan menghargai diri sendiri dan berhasil dalam melakukan pekerjaan.

Dalam satu kuesioner Maslach Burnout Inventory (MBI) memuat 22 butir aitem yang didasarkan pada tiga bagian (section) dalam burnout, yaitu : (1) Section A (Emotional Exhaustion atau kelelahan emosional), (2) Section B (Depersonalization atau kehilangan rasa empati), dan (3) Section C (Reduced of Personal Achievement atau rasa kurang menghargai diri sendiri). Section A terdiri dari tujuh aitem pernyataan, section B terdiri dari tujuh aitem pernyataan, dan section $\mathrm{C}$ terdiri dari delapan aitem pernyataan. Kuesioner MBI ini menggunakan tujuh skala respon yang rentangannya terdiri dari "Tidak Pernah" bernilai 0 sampai "Setiap Hari” bernilai 6 .

Teknik analisis dalam penelitian ada dua, yaitu analisis deskriptif dan korelasional. Analisis statistik deskriptif menggunakan tabel atau diagram yang memuat penjelasan dari hasil perhitungan beban kerja fisik, beban kerja mental, dan kejenuhan kerja (burnout). Dalam hal ini, dilakukan kategorisasi dan interpretasi berdasarkan norma masing-masing skala yang digunakan. Selain itu, dilakukan pula analisis frekuensi dan prosentase dari masing-masing kategori. Sedangkan teknik analisis korelasional menggunakan teknik analisis statistik korelasi Product Moment Pearson untuk menguji hubungan antara variabel $\mathrm{X}_{1}$ dan $\mathrm{Y}$, serta hubungan antara variabel $\mathrm{X}_{2}$ dan $\mathrm{Y}$, serta dilakukan analisis regresi linier berganda (multiple linier regression) untuk menguji hubungan antara variabel $\mathrm{X}_{1}$ dan $\mathrm{X}_{2}$ terhadap $\mathrm{Y}$. 


\section{HASIL DAN PEMBAHASAN}

\section{Gambaran Beban Kerja Fisik Berbasis Ergonomi PT Jasa Marga (Persero) Tbk Cabang Surabaya Gempol}

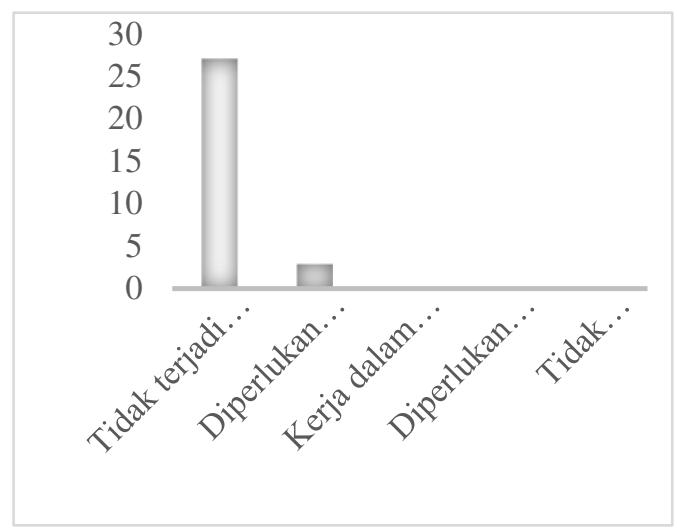

Hasil penelitian beban kerja fisik dengan perhitungan denyut nadi pada 30 karyawan staff non operasional di PT Jasa Marga (Persero) Tbk cabang Surabaya Gempol. Dari grafik tersebut diketahui ada 27 orang (90\%) yang tidak mengalami kelelahan dan 3 orang $(10 \%)$ diperlukan perbaikan. Jadi, sebagian besar karyawan staff non operasional PT Jasa Marga (Persero) Tbk cabang Surabaya Gempol memiliki tingkat beban kerja fisik yang rendah karena tidak terjadi kelelahan dalam melakukan pekerjaan.

\section{Gambaran Beban Kerja Mental Berbasis Ergonomi PT Jasa Marga (Persero) Tbk Cabang Surabaya Gempol}

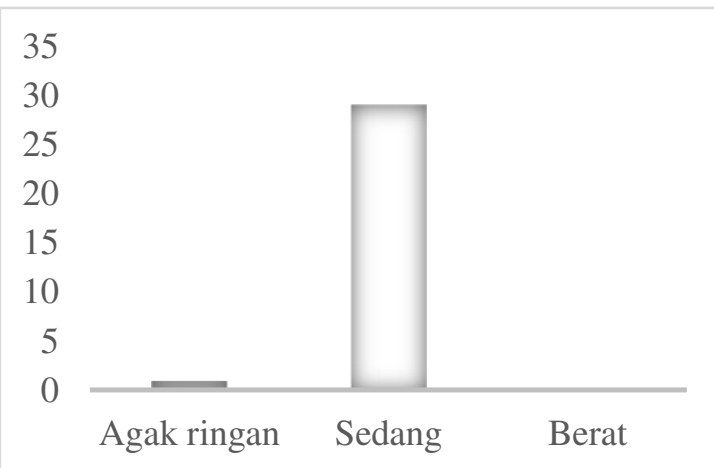

Hasil penelitian beban kerja mental terhadap 30 karyawan tetap staff non operasional di PT Jasa Marga (Persero) Tbk cabang Surabaya Gempol. Dari grafik tersebut diketahui ada 1 orang memiliki kategori beban kerja mental yang agak ringan dan 29 orang dengan beban kerja sedang. Jadi, sebagian besar karyawan staff non operasional PT Jasa Marga (Persero) Tbk cabang Surabaya Gempol memiliki tingkat beban kerja mental pada tingkat sedang.

\section{Gambaran Kejenuhan Kerja PT Jasa Marga (Persero) Tbk Cabang Surabaya Gempol}

Kategorisasi tingkat kejenuhan kerja (burnout) mengacu pada skor masing-masing subskala sesuai rentangan yang telah ditentukan. Masing-masing subskala memiliki rentang kategori yang berbeda sesuai jumlah aitem pada subskala tersebut.

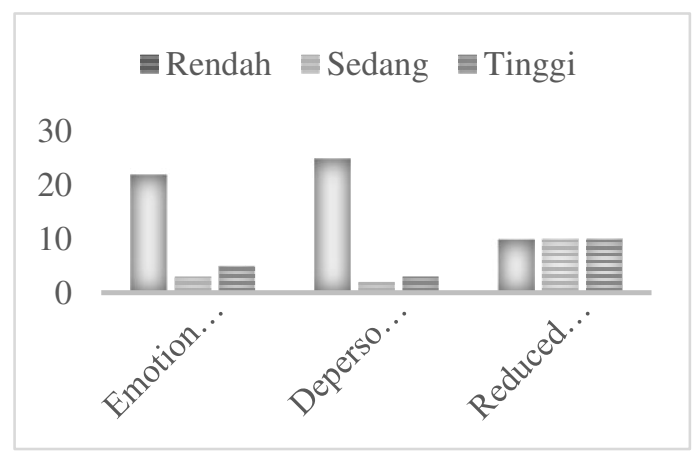

Hasil penelitian kejenuhan kerja pada subskala emotional exhaustion terhadap 30 karyawan tetap staff non operasional di PT Jasa Marga (Persero) Tbk cabang Surabaya Gempol. Dari tabel tersebut diketahui bahwa pada aspek emotional exhaustion ada 22 orang $(73,33 \%)$ berada pada kategori rendah, 3 orang $(10 \%)$ berada pada kategori sedang dan 5 orang $(16,67 \%)$ berada pada kategori tinggi. Sementara pada aspek depersonalization terdapat 25 orang $(83,33 \%)$ berada pada kategori rendah, 2 orang $(6,67 \%)$ berada pada kategori sedang dan 3 orang $(10 \%)$ berada pada kategori tinggi. Sedangkan pada aspek reduced of personal accomplishment terdapat 10 orang $(33,33 \%)$ berada pada kategori rendah, 10 orang $(33,33 \%)$ berada pada kategori sedang dan 10 orang $(33,33 \%)$ berada pada kategori tinggi.

Berdasarkan uji hipotesis, diperoleh hasil bahwa tidak ada hubungan antara variabel $\mathrm{X}_{1}$ dan $\mathrm{Y}$ dengan nilai signifikansi sebesar 0,896, dan tidak ada hubungan antara variabel $\mathrm{X}_{2}$ dan $Y$ dengan nilai signifikansi sebesar 0,493. Hasil uji regresi juga membuktikan tidak ada hubungan antar ketiga variabel $\left(\mathrm{X}_{1}, \mathrm{X}_{2}\right.$, dan $\left.\mathrm{Y}\right)$ 
dengan signifikansi sebesar 0,728. Jadi, beban kerja fisik berbasis ergonomi dan beban kerja mental berbasis ergonomi tidak dapat menjadi prediktor kejenuhan kerja pada karyawan PT Jasa Marga (Persero) Tbk cabang Surabaya Gempol.

\section{PENUTUP}

\section{Kesimpulan}

Mengacu dari temuan penelitian dan pembahasan maka dapat disimpulkan sebagai berikut : (1) Sebagian besar karyawan staff non operasional PT Jasa Marga (Persero) Tbk cabang Surabaya Gempol memiliki tingkat beban kerja fisik yang rendah, (2) Sebagian besar karyawan staff non operasional PT Jasa Marga (Persero) Tbk cabang Surabaya Gempol memiliki tingkat beban kerja mental yang sedang, (3) Sebagian besar karyawan staff non operasional PT Jasa Marga (Persero) Tbk cabang Surabaya Gempol memiliki tingkat kejenuhan kerja (burnout) yang rendah pada aspek emotional exhaustion dan depersonalization. Sedangkan pada aspek reduced of personal accomplishment cenderung jumlah karyawan yang berada pada tingkat tinggi, sedang, dan rendah adalah sama, (4) Tidak ada hubungan antara beban kerja fisik dan kejenuhan kerja (burnout) pada karyawan staff non operasional PT Jasa Marga (Persero) Tbk cabang Surabaya Gempol, (5) Tidak ada hubungan antara beban kerja mental dan kejenuhan kerja (burnout) pada karyawan staff non operasional PT Jasa Marga (Persero) Tbk cabang Surabaya Gempol, (6) Tidak ada hubungan antara beban kerja fisik, beban kerja mental dan kejenuhan kerja (burnout) pada karyawan staff non operasional PT Jasa Marga (Persero) Tbk cabang Surabaya Gempol.

\section{Saran}

Berdasarkan simpulan di atas, maka saran/rekomendasi yang diajukan adalah sebagai berikut : (1) PT Jasa Marga (Persero) Tbk cabang Surabaya Gempol diharapkan dapat tetap mendistribusikan beban kerja fisik dan mental secara seimbang kepada karyawan sesuai dengan kemampuan yang dimiliki oleh masing-masing individu, (2) Karyawan diharapkan dapat meningkatkan kemampuan fisik maupun mental agar siap menghadapi segala tuntutan aktivitas pekerjaan yang diberikan oleh pihak perusahaan sehingga tidak terjadi burn out.

\section{DAFTAR RUJUKAN}

Hutagalung, R. \& Gustomo, A. 2013. Workload Analysis for Planning Needs of Employees in the Corporate Administration Unit PT Timah (Persero) Tbk. The Indonesian Journal of Business Administration, 2 (19): 2290-2297.

Instructions NASA TLX Version 2.0. 2003. NASA Ames Research Center.

Kristanto, A., \& Manopo, R. 2010. Perancangan Ulang Fasilitas Kerja Pada Stasiun Cutting Yang Ergonomis Guna Memperbaiki Posisi Kerja Operator Sebagai Upaya Peningkatan Produktivitas Kerja. Jurnal Informatika, 4 (2): 467-468.

Maharani, P.A. \& Triyoga, A. 2012. Kejenuhan Kerja (Burnout) dengan Kinerja Perawat dalam Pemberian Asuhan Keperawatan. Jurnal STIKES, 5 (2): 167-178.

Munandar, A. S. 2001. Psikologi Industri dan Organisasi. Jakarta: UI Press.

Rahman, U. 2007. Mengenal Burnout Pada Guru. Jurnal Lentera Pendidikan, 10 (2): 216-227.

Ramadhania, N., \& Parwati, N. 2015. Pengukuran Beban Kerja Psikologis Karyawan Call Center Menggunakan Metode NASA-TLX (Task Load Index) pada PT. XYZ. Jurnal disajikan dalam Seminar Nasional Sains dan Teknologi, Fakultas Teknik Universitas Muhammadiyah Jakarta, Jakarta, 17 November.

Shah, S.S.H., Jaffari, A.R., Aziz, J., Ejaz, W., Ul-Haq, I., \& Raza, S.N. 2011. Workload and Performance of Employees. Interdisciplinary Journal of Contemporary Research in Business, 3 (5): 256-267.

Simanjuntak, R.A. 2011. Penilaian Resiko Manual Handling dengan Metode Indikator Kunci dan Penentuan Klasifikasi Beban Kerja dengan Penentuan Cardiovasculair Load. Proceeding Seminar Nasional "Industrial Services", II-81 - II-87. 